DOI: 10.46340/eppd.2020.7.6.15

Natalia Yatsenko

ORCID ID: https://orcid.org/0000-0001-7796-3073

Oles Honchar Dnipro National University, Ukraine

\title{
POLITICAL IDENTITY: \\ CONCEPTUALIZATION \\ OF THE TERM
}

\author{
Наталя Яценко \\ Дніпровський національний університет імені Олеся Гончара, Україна
}

\section{ПОЛІТИЧНА ІДЕНТИЧНІСТЬ: КОНЦЕПТУАЛІЗАЦІЯ ПОНЯТТЯ}

The article is devoted to the consideration of the definition of "political identity", the conceptualization of this definition by different authors and the formulation of author's own vision. The concept is based on the concept of "identity" and its semantic manifestations in various aspects of human life. The main components of political identity are "one's own group" (we are an image) and "the image of another." The classification of forms and sources of identity construction is considered separately: legitimizing identity, identity of resistance, projective identity. The concept of political identity is also considered in terms of symbolic interactionism, functionalism, poststructuralism, neo-Marxism and constructivism. To clearly define the concept of political identity, there are two levels of political identity within which it can be defined institutional identity and identities, which were not political from the very beginning (ethnic, cultural, linguistic ones, etc.).

Keywords: political identity, legitimizing identity, resistance identity, projective identity, concept.

Постановка проблеми. Дослідження політичної ідентичності пов'язано із застосуванням міждисциплінарних підходів, теоретичних й емпіричних методів дослідження. Актуальність вивчення політичної ідентичності визначається формуванням української ідентичності, з одного боку, відображає об'єктивну потребу в стабільному суспільному розвитку; а також в умовах глобалізації ідентичність виступає на особистісному рівні в ролі механізму консолідації національної солідарності і колективістської свідомості. Справедлива точка зору, згідно з якою «соціальні моделі ідентичності - територіальна (регіональна, конфесійна, гендерна, етнічна) набувають в сучасному суспільстві політичний, поліпарадигмальний і міждисциплінарний характер» ${ }^{1}$. Різноманіття підходів до вивчення ідентичності обумовлено складністю і багатомірністю як реального феномена ідентичності, так і самого поняття.

Аналіз останніх досліджень та публікацій. Проблеми політичної ідентичності, її теоретичні та прикладні аспекти викладені у працях зарубіжних науковців, зокрема П. Бергера, 3. Брандта, Ю. Габермаса, М. Емерсона, Е. Еріксона, М. Кастельса, К. Касторіадіса, В. Лапкіна, В. Лота, Т. Лукмана, У. Мішлер, І. Нойманна, С. Перегудової, О. Попової, Т. Райсс, Р. Роуз, І. Семененко, Дж. Серлі, Е. Сміта, Б. Страта, С. Хантінгтона, Ф. Черутті та ін. Істотний внесок в осмислення процесів політичної ідентифікації, значення політичної ідентичності для формування загальнонаціональної, громадянської ідентичності в Україні внесли: А. Астаф'єв, Т. Воропай, С. Горобчишина, О. Добржанська, В. Землюк, Н. Земзюліна, А. Колодій, Л. Нагорна, Г. Палій, Н. Паніна, О. Пашкова, Н. Пелагеша, М. Степико, Ю. Тищенко, Л. Шимченко тощо.

Мета дослідження полягає у висвітленні основних концепцій поняття політичної ідентичності на сучасному етапі.

\footnotetext{
${ }^{1}$ Попова, О.В. (2009). Особенности политической идентичности в странах Европь. Полис, 1, 140-144.
} 
Виклад основного матеріалу. Значення ідентичності визначають три потреби: приналежність до спільноти, позитивна самооцінка і безпека.

Ідентичність поєднує в собі два комплекси уявлень: позитивний і негативний. До глибоко архаїчних пластів свідомості відносяться дуальні протиставлення: «добро-зло», «свій-чужий», «порядок-хаос» тощо ${ }^{1}$. Ідентифікація неможлива без порівняння учасників спілкування, що дозволяє орієнтуватися в «упорядкованому» ментальному світі.

Політична ідентичність визначається Н. I. Тимофєєвим як самовизначення держави, відображене в ключових нормативних і доктринальних документах країни, вкорінене в суспільній свідомості іiі громадян. При цьому ідентичність розглядається дослідником як колективний, а не індивідуальний образ ${ }^{2}$.

Під політичною ідентичністю В.І. Пантін розуміє сукупність найбільш значущих політичних орієнтацій, які багато в чому визначають політичну поведінку і політичні установки людини․․

Суханов В.М. розглядає ідентичність як самосвідомість індивіда або групи. Дослідник вважає, що ідентичність є продуктом самоідентифікації, розуміння того, що людина має якості, що відрізняють його від інших. У цьому контексті «ідентичність можна розуміти як певну стійкість соціокультурних, національних і цивілізаційних параметрів, що створюють соціальну інтегрованість і відчуття самототожності народу» ${ }^{4}$. Ідентичність дозволяє зберегти спадкоємність і являється джерелом цілісності і розвитку, визначає поведінку людей.

Попова О.В. називає політичну ідентичність найважливішою характеристикою політичної свідомості людей, поряд з політичним цінностями і перевагами, політичними установками 5 .

Для В.А. Ачкасової, ідентичність групи позначає цілісність системи соціокультурних характеристик спільності, які включають в себе норми, цінності, ідеали, уподобання та очікування, права і обов'язки індивідів, що реалізуються в соціокультурних ролях і статусах, а також зв'язки і відносини, що виникають в процесі спільної для всіх цих членів спільноти діяльності.

Смислове ядро поняття ідентичності в контексті дослідження I.М. Тимофєєва, складається 3 трьох базових елементів, або кластерів. По-перше, політичну ідентичність можна розглядати як сукупність нормативних уявлень або принципів, на основі яких держава оцінюється своїми громадянами як політична спільнота і які служать йому підставою усвідомлення громадянами країни своєї спільності. В рамках другого кластера ідентичність розглядається як сукупність уявлень, що визначають унікальність політичного співтовариства (держави) через його співвіднесення 3 актуальними іншими маркуваннями його кордонів, через визначення своєї ролі і місця в світі. Політична ідентичність може оцінюватися і як сукупність уявлень та інтерпретацій минулого країни, так і визначатися як особлива інтерпретація історичного минулого, структурована в рамках певної логіки. У звичайних умовах ідентичність проявляється у формуванні певної системи цінностей і норм поведінки жителів регіону. Ї̈̈ можна виявити в фольклорі, переказах, міфах, місцевій інтерпретації історичних подій

Основними компонентами політичної ідентичності, на думку Л.М. Дробіжевої, «є групи, 3 образом яких пов'язує себе індивід, у формуванні яких велике значення мають уявлення про «свою групу» (ми - образ) й емоційно забарвлені відносини» ${ }^{7}$. На думку О.В. Попової, в структуру політичної ідентичності необхідно ввести «образ Іншого», оскільки «важливим показником при оцінці стану політичної ідентичності є стійкість її моделей і ступінь поширення негативізму, на пік

\footnotetext{
${ }^{1}$ Неліпа, Д. (2011). Системний аналіз в політології: теорія, методологія, практика. Київ: Центр учбової літератури, 312.

2 Тимофеев, И.Н. (2008). Политическая идентичность России в постсоветский период: альтернативы и тенденции: монография. Москва: МГИМО-Университет, 175.

${ }^{3}$ Пантин, В.И. (2008). Политическая и цивилизационная самоиндефикация современного российского общества в условиях глобализации. Политические исследования, 3, 12-16.

${ }^{4}$ Суханов, В.М. (2009). Региональная политическая идентичность в России: теоретический анализ исследования, состояние и перспективы: авторефат диссертации на соискание научной степени доктора политических наук. Саратов, 40.

${ }^{5}$ Попова, О.В. (2009). Особенности политической идентичности в странах Европы. Полис, 1, $140-144$.

${ }^{6}$ Палій, Г. (2005). Становлення єдиної національної ідентичності в Україні. Політичний менеджмент, 2 (11), $38-45$.

7 Дробижева, Л.М. (2003). Российская и этническая идентичность: противостояние или совместимость. Россия реформирующаяся: ежегодник. РАН, Институт соџиологии, 212-223.
} 
якої й приходиться розшарування самосвідомості, політизація і фрагментизація моделей ідентичності на окремі субідентічності - професійні, расові, етнічні, релігійні тощо» ${ }^{1}$.

Можна виділити кілька форм і джерел будівництва ідентичності²:

- легітимуюча ідентичність - вводиться пануючими інститутами суспільства для розширення і раціоналізації свого панування над акторами;

- ідентичність опору, яка формується акторами, які перебувають в ситуації їх недооцінки або / і стигматизації логікою панування;

- проективна ідентичність, коли соціальні актори на основі доступного їм культурного матеріалу будують нову ідентичність, яка визначає їх положення в суспільстві і спрямована на перетворення всієї соціальної структури.

Сенс політичної ідентичності, на думку I.М. Тимофєєва, полягає в тому: «цей проект, значущий для суспільства, розділяється громадянами, служить референтним пунктом, щодо якого люди усвідомлюють себе як єдину політичну спільноту і ототожнюють себе із нею». Типами політичної ідентичності виступають: національна (державна), громадянська, етнічна. Ідентичність нації (держави) являе собою складне, мозаїчне утворення, в структурі якого можна виділити специфічні регіональні ідентичності, поєднання і змістове наповнення яких залежить від певного історичного контексту, загальнонаціональних та регіональних традицій і цінностей, соціокультурної специфіки ${ }^{3}$. Дефрагментація політичної ідентичності призводить до формування регіональної ідентичності.

Під терміном «політична ідентичність» Г.А. Айвазян пропонує розуміти детерміновані уявлення індивідів про своє політичне «Я», що складаються в результаті співвіднесення 3 деякими «Іншими» акторами політичного процесу, важливою частиною якого є електоральна поведінка ${ }^{4}$. Для формування політичної ідентичності важливі політична культура і раніше накопичений досвід участі в політизованих взаємодіях, в тому числі й в електоральних процедурах. Онтологічний сенс політичної ідентичності полягає в тому, що вона виступає результатом формування політичного світогляду індивіда, а також стимулює існування відмінностей в засобах вираження, формах, змісті та підходах до тих чи інших політичних феноменів, акторів і політичних процесів.

Ідентичність має на увазі занадто багато, якщо вона вживається в «сильному» значенні і занадто мало, якщо в «слабкому»5. «Сильне» значення ідентичності - це фундаментальні концепції, що зберігають загальновживане значення терміну, що підкреслюють сталість характеристик протягом деякого часу або схожість трансіндивідуальних якостей. Основні посили такого розуміння: 1) політична ідентичність $\epsilon$ або у всіх, або кожен повинен прагнути іiї придбати; 2) політична ідентичність $\epsilon$ або повинна бути у представників всіх груп населення; 3) політична ідентичність людей і груп може бути неусвідомленою. Вона $є$ щось, що необхідно виявити, але і також щось, у чому можна помилитися; 4) сила поняття колективної політичної ідентичності має на увазі міцний зв'язок між членами групи та в її однорідність.

«Слабке» розуміння політичної ідентичності пориває із загальновживаними концепціями i розглядає ідентичність як щось багатогранне, нестабільне, що знаходиться в постійному русі, випадкове, неоднорідне. Воно пов'язане з відсутністю впевненості в тому, що значення «політична ідентичність» означає саме ідентичність ${ }^{6}$. I, нарешті, ідентичність в іiі «слабкому» значенні може виявитися «слабкою категорією» для теоретичної роботи.

Згідно з М. Кастельсом, ідентичність $€$ «процес конструювання змісту на основі певної культурної властивості або відповідної сукупності культурних властивостей, які мають пріоритет по відношенню до інших джерел сенсу» ${ }^{7}$. М. Кастельс запропонував класифікацію форм і джерел будівництва ідентичності: 1) легітимуюча ідентичність - вводиться пануючими інститутами

\footnotetext{
${ }^{1}$ Попова, О. В. (2009). Особенности политической идентичности в странах Европы. Полис, 140-144.

${ }^{2}$ Миненков, Г.Я. (2005). Политика идентичности с точки зрения современной теории. Политическая наука, 2005, 3, 21-28.

${ }^{3}$ Сукачов, В.В. (2005). Політична довіра як складова соціального капіталу громадянського суспільства: автореферат дисертації на здобуття наукового ступеня кандидата політичних наук. Дніпропетровськ, 17. ${ }^{4}$ Айвазян, Г.А. (2010). Политическая идентичность - аналитический инструмент политологии. Социиум и власть, 3 (27), 29-32.

${ }^{5}$ Brubaker, R. (2000). Beyond identity. Theory and society. Dordrecht, 29, 1.

${ }^{6}$ Шимченко, Л. А. (2006). Громадянська ідентифікація особи як чинник формування української політичної нації: автореферат дисертації на здобуття наукового ступеня кандидата філософських наук. Київ, 17.

${ }^{7}$ Castells, M. (1997). The power of identity. Cambridge, Mass: Blackwell.
} 
суспільства для розширення i раціоналізації свого панування над соціальними акторами; 2) ідентичність опору - формується акторами, які знаходяться в ситуації їх недооцінки i / або стигматизації логікою панування; 3) проектна ідентичність - соціальні актори на основі доступного їм культурного матеріалу будують нову політичну ідентичність, яка перекриває їх положення в соціумі та спрямована на перетворення всієї соціальної й політичної структури суспільства.

Загальновизнано, що в сучасному суспільстві ідентичності стають все більш численними, фрагментованими, мінливими, залежними від контексту. За словами Стюарта Холла, «мова не стільки про те, «хто ми» $\mathrm{i}$ «звідки», скільки про те, чим ми можемо стати, як нас представляють інші й як це співвідноситься з нашими власними уявленнями про себе... Ідентичності створюються в процесі репрезентації, а не за їі рамками». ${ }^{1}$. Говорячи іншими словами саме в процесі політичної дії формується політична ідентичність, що дозволяє громадянину здійснювати електоральний вибір, тим самим впливаючи на трансформацію політичної системи держави.

Зазначений дискурс за визначенням має враховуватись усіма учасниками політичного процесу. За словами відомого соціолога Крейга Келхуна, «політика ідентичності... була невід'ємною частиною сучасної політики і суспільного життя протягом сотень років. Однак ій доводилося змагатися з різними універсалізуючими концепціями..., відкидали відмінності, i ця обставина вплинула на формування природи не тільки політики, а й наукового мислення» ${ }^{2}$.

Для формування політичної ідентичності дуже важливі політична культура і раніше накопичений досвід участі в політизованих взаємодіях, в тому числі й в електоральних процедурах. Онтологічний сенс політичної ідентичності полягає в тому, що вона виступає результатом формування політичного світогляду індивіда, а також стимулює існування відмінностей в засобах вираження, формах, змісті і підходах до тих чи інших політичних феноменів, акторів і політичних

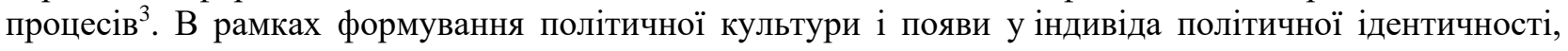
істотне значення мають практики політичної соціалізації, в результаті яких громадянин позиціонує себе в електоральному полі.

Поняття політичної ідентичності також можна розглянути з точки зору символічного інтеракціонізму, функціоналізму, поструктуралізму, неомарксизму і контструктивізму.

Відповідно до символічного інтеракціонізму, ідентичність дозволяє стати індивіду для себе самого об'єктом. Застосовуючи чужу думку і позиції по відношенню до самих себе, ми будуємо свої позиції по відношенню до Інших. Політична ідентифікація включає в себе наслідування важливих представників суспільства, при здійсненні якого відбувається привласнення індивідом одночасно безлічі соціальних ролей. Організоване суспільство або соціальна група надає особистості цілісну ідентичність «узагальненого Іншого». Кінцева ступінь ідентифікації досягнута, коли людина може увійти в політичне життя суспільства і не тільки рефлексувати з приводу своєї реакції на конкретні події або політичні інститути, а й враховувати при цьому потреби, вимоги соціальної групи, законів, організацій, держави i, навіть, усієї світової спільноти ${ }^{4}$.

Функціоналізм вивчає політичну ідентичність у рамках політичної культури, де під нею розуміється ототожнення індивіда з узагальненими Іншими. Центральна роль відводиться ціннісним орієнтаціям, які виступають в якості особливої мотиваційної системи ${ }^{5}$ Ціннісні орієнтації допомагають людині усвідомити як свою ідентичність, так і свою відмінність від представників іншої системи поглядів. Політична ідентичність виступає об'єднуючим і дистанцюючим засобом по відношенню до інших індивідів, політичним організаціям, інституціям влади. Індивід будує свою політичну реальність за схемою «свої - в чомусь близькі - чужі - ворожі».

У рамках поструктуралізму політична ідентичність визначається за допомогою ототожнення себе з індивідами, які мають подібні габітуси і життєві траєкторії, на основі чого відбувається конструювання класів. «Політична ідентичність - окремий випадок соціальної ідентичності, раціональної та рефлексивної за своєю природою. Ця характеристика є символічним засобом

\footnotetext{
${ }^{1}$ Hall, S. (1996). Introduction. Who Needs 'Identity'? Sage: Questions of cultural identity.

${ }^{2}$ Calhoun, C. (1994). Social theory and the politics of identity. Social theory and the politics of identity. Oxford, Blackwell.

${ }^{3}$ Тищенко, Ю.А. (2010). Громадянське суспільство в Україні та «політика ідентичності». Київ: Україна, 76.

4 Заковоротная, М. В. (1999). Идентичность человека социально-философские аспекты. Ростов-на-Дону:

Северо-Кавказский научный центр высшей школы, 200.

${ }^{5}$ Абельс, Х. (1999). Интеракиия, идентичность, презентаџия. Введение в интерпретативную социологию.

СПб.: Алетейя, 265.
} 
об’єднання з одними і дистанціювання від інших агентів поля політики, найважливішим засобом мобілізації людей для політичної діяльності». Таким чином, індивід визначає свою політичну позицію за допомогою свого досвіду і вибудуваної лінії сприйняття і оцінки політичної ситуації.

Будучи раціональною та рефлексивною за своєю суттю, політична ідентичність в рамках структуралізму розглядається як ситуаційна і трансверсальна (надситуаційна). Вивчаючи ситуаційну політичну ідентичність, структуралісти стверджують, що вона пов'язана 3 політичною практикою і для зміни іiі досить нав'язаних ззовні схем аналізу ситуації та політичного рішення. Ситуаційна політична ідентичність $є$ підставою для побудови політичної ідентифікації людини, вони повинні бути осмислені і прийняті нею, поширені на всі пов'язані ситуації. Ситуаційна політична ідентичність $€$ обумовленою тією чи іншою ситуацією і відносно легко мінлива.

Трансверсальна політична ідентичність відображає весь політичний досвід і значимість політичних відносин для індивіда. Вона є стійкою і тривалою. Надситуаційна політична ідентичність виникає на основі внутрішньої роботи суб'єкта з оцінки та прийняття (або неприйняття) ситуаційних ідентичностей і проходить чотири стадії формування: 1) виникнення емпатії до персоніфікованої позиції в поле політики, 2) становлення ситуаційної політичної ідентичності на основі емпатії, 3) усвідомлення ситуаційної політичної ідентичності та формування надситуаційної ідентичності, 4) прийняття індивідом усвідомленої стійкої ідентичності як особистісної політичної ідентичності.

Неомарксизм розкриває поняття політичної ідентичності через поняття класової свідомості. Індивід обирає політичні партії, й його політична поведінка формується, виходячи із співвіднесення економічного становища свого класу і його потреб.

Класова свідомість включає в себе формування економічного інтересу класу на основі потреб, після відбувається його усвідомлення. Ідеологія класу $-\epsilon$ вища форма теоретичного вираження корінних інтересів певного класу, найбільш розвиненою формою класової самосвідомості. Класова свідомість включає три рівня. На першому типологічному рівні індивіди визначають свою схожість, ототожнюючи себе тільки за зовнішніми ознаками. На наступному ідентифікаційному рівні виникає групова самосвідомість діяльності та умов життя, потреб і інтересів. I тільки на останньому рівні солідарності відбувається повне ототожненні себе з групою за допомогою усвідомлення єдності інтересів і цінностей.

Згідно марксистської методології класова свідомість обов'язково знаходить своє вираження в політичних навчаннях і програмах. 3 точки зору конструктивізму політична ідентичність постає як певний набір символічних соціально сконструйованих значень, які поділяються усіма членами групи, ідентичність $є$ завжди відкритою для нових інтерпретацій і перетворень.

Для більш чіткого визначення поняття політичної ідентичності слід виділити два рівня політичної ідентичності в рамках, в яких вона може бути визначена. Перший рівень політичної ідентичності можна визначити як інституційний. Тут політична ідентичність пов' язана безпосередньо зі структурою політичного, наприклад, партіями, державою тощо. Другий же рівень політичної ідентичності включає в себе ідентичності, які з самого початку не були політичними, наприклад, етнічна, культурна, мовна тощо. Ці види ідентичності стають політизованими з того моменту, коли їх вимоги в свій захист, так чи інакше пов'язані з владою.

Висновок. Політичну ідентичність слід визначити як особливий вид соціальної ідентичності, спрямований на самовизначення індивіда / групи в політичному плані за допомогою ідентифікації 3 політичними інститутами і передбачає участь груп та індивідів у політичному процесі, а також взаємини всередині групи й з іншими подібними групами. Політична ідентичність ототожнення індивідом себе з певною політичною групою або політичним лідером передбачає прийняття поглядів і переконань даної політичної групи.

Говорячи про українську політичну свідомість, слід виокремити наступні чинники, що сприятимуть іï формуванню:

1) легітимність політичної влади, стабільність конституційних і правових норм державності;

2) підтримка відчуття символічності в національній свідомості, демократичне вирішення мовного питання;

3) громадянська ідея як підгрунтя для створення та реалізації політичних проектів з метою формування уявлення громадян про державу;

\footnotetext{
${ }^{1}$ Фарукшин, М. Х. (2009). Политическая идентичность в контексте политической культуры. Казань: Центр инновационных технологий, 44.
} 
4) консолідація суспільства задля реалізації цілей суспільно-політичного розвитку;

5) створення єдиного інформаційно-комунікаційного простору для формування національної свідомості громадян;

6) розробка та популяризація спільної системи цінностей, що поєднає людей.

\section{References:}

1. Abels, H. (1999). Interakcija, identichnost, prezentacija. Vvedenie v interpretativnuju sociologiju [Interaction, identity, presentation. Introduction to Interpretive Sociology]. SPb.: Aletejja, 265. [in Russian].

2. Ajvazjan, G. A. (2010). Politicheskaja identichnost - analiticheskij instrument politologii [Political identity is an analytical tool of political science]. Socium $i$ vlast [Society and power], 3 (27), 29-32. [in Russian].

3. Drobizheva, L. M. (2003). Rossijskaja i jetnicheskaja identichnost: protivostojanie ili sovmestimost [Russian and ethnic identity: confrontation or compatibility]. Rossija reformirujushhajasja: ezhegodnik. RAN, Institut sociologii [Reforming Russia: Yearbook. RAS, Institute of Sociology], 212-223. [in Russian].

4. Zakovorotnaja, M. V. (1999). Identichnost cheloveka socialno-filosofskie aspekty [Human identity socio-philosophical aspects]. Rostov-na-Donu: Severo-Kavkazskij naukhovij centr vysshej shkoly. [in Russian].

5. Minenkov, G. Ja. (2005). Politika identichnosti s tochki zrenija sovremennoj teorii [Identity politics from the point of view of modern theory]. Politicheskaja nauka [Political Science], 3, 21-28. [in Russian].

6. Nelipa, D. (2011). Systemnyj analiz v politologiyi: teoriya, metodologiya, praktyka [System analysis in political science: theory, methodology, practice]. Kyiv: Centr uchbovoyi literatury. [in Ukrainian].

7. Palij, G. (2005). Stanovlennya yedynoyi nacionalnoyi identychnosti v Ukrayini [Formation of a single national identity in Ukraine]. Politychnyj menedzhment [Political management], 2 (11), 38-45. [in Ukrainian].

8. Pantin, V. I. (2008). Politicheskaja i civilizacionnaja samoindefikacija sovremennogo rossijskogo obshhestva v uslovijah globalizacii [Political and civilizational self-identification of modern Russian society in the context of globalization]. Politicheskie issledovanija [Political studies], 3, 12-16. [in Russian].

9. Popova, O. V. (2009). Osobennosti politicheskoj identichnosti v stranah Evropy [Features of political identity in European countries]. Polis, 1, 140-144. [in Russian].

10. Sukachov, V. V. (2005). Politychna dovira yak skladova socialnogo kapitalu gromadyanskogo suspilstva [Political trust as a component of the social capital of civil society]: avtoreferat dysertatsiyi na zdobuttya naukovoho stupenya kandydata filosofskykh nauk [abstract of the dissertation for the degree of Candidate of Philosophical Sciences]. Dnipropetrovsk. [in Ukrainian].

11. Timofeev, I. N. (2008). Politicheskaja identichnost Rossii v postsovetskij period: alternativy i tendencii [Political Identity of Russia in the Post-Soviet Period: Alternatives and Trends]. Moscow: MGIMO-Universitet. [in Russian].

12. Tyshhenko, Yu. A. (2010). Gromadyanske suspilstvo v Ukrayini ta «polityka identychnosti» [Civil society in Ukraine and "identity politics"]. Kyiv: Ukrayina. [in Ukrainian].

13. Farukshin, M. H. (2009). Politicheskaja identichnost v kontekste politicheskoj kultury [Political identity in the context of political culture]. Kazan: Centr innovacionnyh tehnologij. [in Russian].

14. Shymchenko, L. A. (2006). Gromadyanska identyfikaciya osoby yak chynnyk formuvannya ukrayinskoyi politychnoyi naciyi [Civic identification of a person as a factor in the formation of the Ukrainian political nation]: avtoreferat dysertatsiyi na zdobuttya naukovoho stupenya kandydata filosofskykh nauk [abstract of the dissertation for the degree of Candidate of Philosophical Sciences]. Kyiv. [in Ukrainian].

15. Suhanov, V. M. (2009). Regionalnaja politicheskaja identichnost v Rossii: teoreticheskij analiz issledovanija, sostojanie i perspektivy [Regional political identity in Russia: theoretical analysis of the study, state and prospects]: avtoreferat dysertatsiyi na zdobuttya naukovoho stupenya kandydata politychnykh nauk [dissertation abstract for the degree of Candidate of Political Science]. Saratov. [in Russian].

16. Calhoun, C. (1994). Social theory and the politics of identity. Social theory and the politics of identity. Oxford, Blackwell. [in English].

17. Castells, M. (1997). The power of identity. Cambridge, Mass: Blackwell. [in English].

18. Brubaker, R. (2000). Beyond identity. Theory and society. Dordrecht, 29, 1. [in English].

19. Hall, S. (1996). Introduction. Who Needs 'Identity'? Sage: Questions of cultural identity. [in English]. 